\title{
Phytoprotection
}

\section{Transgenic Plants for Insect Resistance}

\section{Marc Giband}

Volume 79, numéro 4, 1998

OECD Workshop - Sustainable Pest Management, Safe Utilization of New Organisms in Biological Control. Montréal, Québec, Canada. September 27-30, 1998.

Atelier de l'OCDE - Gestion durable des ennemis des cultures,

Utilisation sécuritaire de nouveaux organismes de lutte biologique.

Montréal, Québec, Canada. 27-30 Septembre 1998.

URI : https://id.erudit.org/iderudit/706169ar

DOI : https://doi.org/10.7202/706169ar

Aller au sommaire du numéro

Éditeur(s)

Société de protection des plantes du Québec (SPPQ)l

ISSN

0031-9511 (imprimé)

1710-1603 (numérique)

Découvrir la revue

Citer cet article

Giband, M. (1998). Transgenic Plants for Insect Resistance. Phytoprotection, 79(4), 121-126. https://doi.org/10.7202/706169ar d'utilisation que vous pouvez consulter en ligne.

https://apropos.erudit.org/fr/usagers/politique-dutilisation/ 


\title{
Transgenic Plants for Insect Resistance
}

\author{
Marc Giband
}

CIRAD-CA, Laboratoire de Biologie Cellulaire, INRA, Centre de Versailles, Route de Saint-Cyr, 78026 Versailles Cedex, France

Less than ten years after the publication of the first reports describing the regeneration of insect-resistant plants, such transgenic plants expressing $\delta$-endotoxins from the soil bacterium Bacillus thuringiensis were commercially released. These transgenic plants have shown their efficiency in controlling some of the major lepidopteran and coleopteran insect pests of cotton, corn and potato, and represent novel tools for insect control. Despite the obvious usefulness of this novel technology, some questions remain regarding the safe and durable utilization of these plants. In particular, the problem of the emergence of toxin-resistant insects deserves particular attention. Various strategies aimed at preventing or delaying the development of such resistance have been envisaged, but experimental data on the management of insectresistant plants are still scarce. Thus, future work should concentrate on defining the best strategy(ies) for the durable deployment of these transgenic plants.

\section{INSECT-RESISTANT TRANSGENIC PLANTS EXPRESSING GENES ENCODING $\delta$-ENDOTOXINS FROM BACILLUS THURINGIENSIS}

In 1987, the first plants expressing $\delta$-endotoxins (crylA-type) from Bacillus thuringiensis $(B t)$ were produced. These plants, which harboured bacterial (native) genes, showed good levels of re- sistance towards early instar larvae of toxin-sensitive insect species (Manduca sexta). Nevertheless, when challenged with the less sensitive economically important species, or with later instar larvae, the resistance imparted was not as significant. This lack of efficient protection could be attributed to the low level of Cry protein accumulation, which is due to the poor expression of the bacterial cry genes in transgenic plants. In an effort to enhance gene expression, "synthetic" cry genes were built. These genes, in which the nucleotide sequence is modified (without changing the amino-acid sequence) so as to eliminate features that could potentially hinder gene expression, allowed a much higher level of protein accumulation (up to a 500 -fold increase when compared to bacterial genes) and consequently, a much higher level of protection. To date, numerous plant species have been transformed with different synthetic cry genes and have been shown to be highly resistant to a number of economically important insect pests (for a review, see Mazier et al., 1997).

Since 1996, transgenic potato, cotton and corn harbouring respectively the cryIIIA, $\operatorname{cry} I A(c)$ and $\operatorname{crylA}(b)$ or $\operatorname{crylA}(c)$ gene have been granted approval for commercial release in a number of countries (the USA, Canada, Australia, Argentina, the EU, South Africa and Japan). In it's introductory year, Bt cotton represented $12 \%$ of the US acreage, while Bt corn accounted for approximatively $9 \%$ of the US corn crop. It is estimated that in 1997, over 20 million acres could have been 
devoted to the different $B t$ crops (Krattiger, 1997). In the future, an increasing acreage will be covered by insect-resistant crop plants, and without the implementation of appropriate measures aimed at delaying insect resistance, this novel technology may be short-lived.

\section{THE DEPLOYMENT OF BT PLANTS}

The problem of the low level of expression of Bt toxin genes has been solved through the introduction of synthetic codon-optimized genes, thus leading to a great improvement in the resistance imparted to the transformed plants. With the large scale release of such plants, the major concern now resides in the proper deployment and use of these plants. Indeed, if care is not taken in the way these plants are managed, the pressure of selection to which insect pests will be exposed will be such that resistance to $B t$ toxins will occur, making this technology short-lived.

\section{Insect resistance to $B t$ toxins}

Insects have demonstrated their ability to develop resistance to chemical pesticides, and are expected to do the same with $B t$ toxins. In fact, resistance to $B t$ toxins has developed in a number of insects species (in laboratory experiments but also in the field), including economically important pests such as the diamondback moth (Plutella xylostella), the Indianmeal moth (Plodia interpunctella), the tobacco budworm (Heliothis virescens), the beet armyworm (Spodoptera exigua), the Egyptian cotton leafworm (S. littoralis) or the Colorado potato beetle (Leptinotarsa decemlineata) (for a review, see Tabashnik, 1994a). The mode of resistance to $B t$ toxins, and it's genetic basis are complex, and vary with the strain of insect studied. In most cases the resistance could be attributed to a change in the binding affinity of the receptors (or binding sites) of the brush border membrane of the midgut; however, other mechanisms of resistance have also been described. In two strains of Btresistant Indianmeal moths, resistance was correlated with the lack of a major gut proteinase that activates $B t$ protoxins (Oppert et al., 1997), while in a resistant $H$. virescens strain, gut enzymes were shown to process protoxins more slowly and degrade toxins faster than enzymes from a susceptible strain (Forcada et al., 1996). Similarly, in S. littoralis, fifth instar larvae showed an increase in gut proteinase activity which was associated with a loss of sensitivity to the CrylC toxin (Keller et al., 1996). In the case where resistance is associated with a modification of the gut proteinases, it can be expected that broadspectrum resistance will occur if protoxins rather than activated toxins are used. Where it could be attributed to a modification in receptor binding, resistance was shown to be either specific of the toxin used for selection (and to closely related toxins)(Ferré et al., 1991; Tabashnik et al., 1993), but this type of mechanism was also shown to confer wider cross-resistance to more distant Bt toxins (Tabashnik et al., 1997). Even though in at least one case the inheritance of resistance showed a paternal effect in S. littoralis (Chaufaux et al., 1997), it is usually autosomally inherited, and partially to completely recessive with one or a few genes involved. Nevertheless, in a strain of diamondback moth which had evolved a high level of resistance to $B$. thuringiensis subsp. kurstaki and moderate resistance to CrylC in the field, and was further selected in the laboratory for resistance to the latter toxin, resistance to CryIC (which was inherited independantly from resistance to CrylA(b)) was found to show a dose-dependant dominant inheritance (Liu and Tabashnik, 1997).

Thus, resistance to $B t$ toxins does not involve a single mechanism, but is a rather complex phenomenon whose genetics varies greatly between insect species, but also within a species: different toxin-resistant strains of $H$. virescens were analysed, and it was shown that resistance mapped at three different genetic loci (Heckel, 1994).

\section{Managing insect resistance to plants expressing $B t$ toxins}

In view of the high probability that insects will evolve resistance to Bt plants, many agree that such plants are not a 
stand-alone solution to pest management, but rather represent a novel tool that should be integrated in a more general effort. Various strategies aimed at managing the development of insect resistance to transgenic plants have been proposed (Mallet and Porter, 1992; McGaughey and Whalon, 1992, Tabashnik, 1994b). Some of these tactics may be specific to transgenic insecticidal plants (level of expression of the transgene, tissue-specific or inducible promoters, number of genes), while others are commonly used in Integrated Pest Management (IPM) schemes (crop rotations, temporal or spacial refuges, mosaic planting). Nevertheless, these various strategies are based on assumptions and rely on untested mathematical models which cannot take into account the full complexity of the problem, and may therefore have to be adapted to each particular situation.

For practical reasons, the strategy that is favored for the transgenic $B t$ plants that are at present released is that of a combination of a high dose of toxin, delivered through the use of synthetic cry genes and strong constitutive promoters, with the implementation of separate spacial refuges consisting of non-transformed plants. Thus, for crylA(c)-expressing cotton (Bollgard ${ }^{\mathrm{TM}}$, Monsanto), a $4 \%$ non-treated refuge, or a $25 \%$ refuge that can be treated with insecticides other than $B t$ products are mandated, while in crylA(b)-expressing corn (YieldGard ${ }^{\mathrm{TM}}$, Monsanto; Maximiz$\mathrm{er}^{\mathrm{TM}}$, Novartis; NatureGard ${ }^{\mathrm{TM}}$, Mycogen), a $5 \%$ non-treated refuge is required (Krattiger, 1997).

This "high-dose/refuge" strategy is thought to be the most promissing one to manage and delay insect resistance to the transgenic plants that are at present released. In this scheme, the dose of toxin that is delivered should be high enough so as to kill all the insects heterozygous for a resistance allele (RS), while the refuges should allow the emergence of homozygous susceptible insects (SS) which could then mate with the RS insects, thus "diluting" the resistance allele and avoiding the emergence of homozygous resistant insects (RR) and a build-up of phenotypical resistance through the fixation of the resistance allele.

\section{POTENTIAL PITFALLS OF THE CURRENT STRATEGY}

To be effective, the strategy that is recommended at present implies that (i) the plants deliver doses of toxin high enough to kill all RS heterozygous insects, and (ii) the refuges provide susceptible SS insects which, through random mating with insects escaping selection on the Bt plants, will prevent the fixation of the resistance allele. For the durable deployment of transgenic insect-resistant plants, it is important that these criteria be met.

\section{Defining "high doses" of toxin}

Insect species show a wide range of sensitivity towards different $B t$ toxins, and the genes that have been transferred into plants are those that demonstrate the highest activity towards the targetted insect pest. In the case damages to a crop can be attributed to one major pest (the Colorado potato beetle or the European corn borer), achieving a high dose of toxin can be a matter of selecting transgenic lines that show high levels of transgene expression. In cotton cropping systems, the situation is somewhat more complicated, with several pests (mainly $H$. virescens and Helicoverpa zea) causing most damages in the continental USA, while in other cotton-producing areas in which transgenic plants have been or are susceptible to be released (Australia, Africa, South-East Asia), the main pest is Helicoverpa armigera. If the transgenic cotton plants at present commercialized show good control of $H$. virescens, control of the two other pests is not as efficient. This is not a surprise, since the two latter species are significantly less sensitive to the CrylA(c) toxin than the former, even though this toxin is the most potent one against these species. Thus, some plants might qualify as "high dose expressors" relative to one target species, but not relative to other target pests. In such a case, it can be feared that resistance to the toxin that is expressed in the plant may occur 
fairly quickly in the species that are exposed to sub-lethal doses.

In most cases, the Cauliflower Mosaic Virus (CaMV) 35S RNA promoter (or derivatives thereof) is used to drive the expression of the transgene. This promoter is often considered as constitutively expressed, but it's activity has been shown to vary in different tissues and during plant development, but also under different environmental conditions. Thus, some plant tissues might not express the toxin at high levels, and insects feeding on these particular tissues will once again not be exposed to optimal doses of the toxin. It is concievable that in such cases, some insects feeding on plant parts that express the toxin poorly will be allowed to reach later less sensitive larval instars before encountering higher doses of the toxin as they migrate from one tissue to another. There is no doubt that such a scenario would cause a high pressure of selection, and lead to a rapid increase in the number of toxin-resistant individuals.

These examples testify on the difficulty of determining what a "high dose" really means. It is obvious that for some insect species this dose can fairly easily be achieved, but for others, the task may be more difficult. This problem is further complicated by the fact that in different geographical areas, a same insect species can show a range of susceptibility to a given toxin. For example, 8- and 16-fold ranges of susceptibility to $B$. thuringiensis subsp. kurst$a k i$ were found in unexposed field populations of $H$. virescens and $H$. zea respectively (Stone and Sims, 1993).

\section{Determining adequate refuges}

In combination with plants delivering high doses of toxin capable of killing both SS ad RS individuals, refuges, or plants that do not express Bt toxins, on which SS insects can multiply are to be implemented. These refuges allow a sufficient numbers of SS insects to develop, thus ensuring a continual influx of susceptible genes into the population and preventing, through random mating, the built-up of resistance.
Several studies tend to show that separate refuges work better than infield refuges in preventing resistance built-up (Tabashnik, 1994b; Ramachandra et al., 1998). This is probably due to insect movement between plants, which may not allow a sufficient number of SS individuals to develop if larvae move off non-expressing plants to those that do express a $B t$ toxin.

The effectiveness and optimal size of the refuges will largely depend on the target pest's behaviour (movement from plant to plant, mating and host finding...), the initial frequency of the resistance allele in the population, but also on the acceptance of losses in unprotected stands. Benefits of the refuges will be greatest if resistance is a recesive trait, and if the frequency of the resistance allele is low. Furthermore, critical assumption in this scheme include random mating between insects developing on $B t$ plants and those developing on refuges, and low mortality of SS insects on toxin-free plants. At this point, we have to admit that experimental data on cerain of these aspects are scarce, even if research efforts are currently under way.

If certain of these assumptions/conditions can fairly easily be met or verified (low mortality on toxin-free plants), other are more problematic, and some experimental data are in contradiction with these conditions. Thus, in many models used for simulation, the initial frequency of the resistance allele is estimated at $10^{-4}-10^{-6}$, while Gould et al. (1997) estimated this frequency in a field population of $H$. virescens to be at $1.5 \times 10^{-3}$. Similarly, it is assumed that random mating between populations will occur, which is not obvious if resistant (or RS heterozygous) insects show a delay in development. In fact, in laboratory experiments, Gould et al. (1991) noted a delay in the development of toxin-adapted $H$. virescens larvae fed on a toxin-containing diet when compared to the rate of development of sensitive larvae raised on a toxin-free diet. This type of behaviour could lead to assortive mating rather than random mating, and cause intense selection and 
rapid development of resistance. Finally, rather than being recessive, the inheritance of resistance has been shown to vary from recessive to partially dominant (see above). In this latter case, built-up of resistance will occur rapidly unless very high doses of toxin, capable of killing the RS resistant insects, are delivered by the plants.

\section{Other considerations}

Other circumstances may also speed up the emergence of toxin-resistant insects. The cotton bollworm (H. zea) is an insect pest that feeds on both corn and cotton, two crops that have been transformed with the $c r y \mid A(b)$ and crylA(c) genes respectively, and are commercially available. Although both toxins show some activity towards this insect, $\operatorname{Cryl} A(b)$ is much less potent than CrylA(c). With the success of these plants, and the increasing acreages that is devoted to their cultivation, it is possible that these insects will encounter CrylA(b)-expressing corn before moving on to CrylA(c)-producing cotton; such movement will undoubtedly result in the selection of toxin-resistant insects.

Another point of concern is related to the nature of the coding sequence that is transferred to the plant genome. Most plants that are at present commercialized harbour a truncated version of the Bt gene. Nevertheless, Monsanto's Bollgard ${ }^{\mathrm{TM}}$ cotton express a gene encoding the protoxin, which has to be activated by gut proteinases to exhert it's insecticidal activity. One mechanism by which insects develop resistance involves gut proteinases (Oppert et al., 1997), and exposure to a single protoxin might select for this type of resistance, which will be broad-spectrum and preclude the use of $B t$-based sprays.

\section{CONCLUSIONS AND PROSPECTS}

Plants that express $B t$ toxins have proven their effectiveness in controlling some of the major pests in various cropping systems. Because the toxin they express is environmentally benign, has a fairly narrow spectrum of activity, and can cause high mortality to the target pest, these transgenic plants represent powerful tools to be integrated in IPM schemes. Various studies have shown the benefit of these plants in enhancing the population of beneficials and reducing the number of secondary pests when compared to chemical pesticidetreated plots (for example, Feldman and Stone, 1997).

Nevertheless, we have to admit that our current knowledge on the durable deployment of these plants is sometimes limited. In this respect, the greatest needs concern the prevention of the build-up of insect resistance to the $B t$ toxins. Our lack of knowledge stems from the novelty of this technology and our lack of experience in the large scale cultivation of such crops, the complexity of the mechanisms involved in insect resistance, and the difficulty in designing experiments that will answer our questions (laboratory, greenhouse or even small scale trials seldomly reflect the situation in the field) and research efforts should concentrate on these aspects.

The plants that are currently released express a single insect-resistance gene, and are considered by many as first generation products. The second generation of transgenic insect-resistant plants will probably harbour more than one resistance trait. These traits could be imparted by other transgenes (encoding $B t$ toxins with different binding sites or other entomopathogenic molecules) or by the host plant itself(okra leaf, high terpenoid, nectariless in cotton; DIMBOA in corn; glandular trichomes in potato). The identification of novel sources of resistance is an area that is particularly active, and different potential candidate genes of various sources are currently under study (for a review, see Carozzi and Koziel, 1997). Similarly, protein engineering holds promises in improving the efficiency of current entomopathogenic molecules (Jongsma et al., 1996; Rajamohan et al., 1996), and this type of research certainly deserves attention.

With respect to this technology and to the benefits that can be expected 
from it, some questions deserve to be addressed:

(i) Since our body of knowledge on the management of $B t$ plants on a large scale is limited, should the current "first generation" of plants be used to aquire this knowledge, with the risk of curtailing the future use of $B t$ toxins? If not, how can we acquire the knowledge that is at present lacking?

(ii) Some of the farmers that would benefit the most from this technology belong to developing countries. How can we assure that this technology is safely transferred to such countries, and that as many as possible can benefit from it?

(iii) Should all crops (including perennial plants) be targetted for transformation with insect resistance genes, and should they be allowed to be deployed under any circumstance? If not, what body should assess the potential risks and benefits, and regulate the large scale release of these plants?

\section{REFERENCES:}

Carozzi N and Koziel M (1997) (Eds.) Advances in Insect Control. The Role of Transgenic Plants. Taylor \& Francis, London.

Chaufaux J, Müller-Cohn J, Buisson C, Sanchis V, Lereclus D, and Pasteur N (1997) J. Econ. Entomol. 90: 873-878

Feldman J, and Stone T (1997) in Advances in Insect Control. The Role of Transgenic Plants. Carozzi $\mathrm{N}$ and Koziel M (Eds). Taylor \& Francis, London. pp 49-61

Ferré J, Real MD, van Rie J, Jansens S, and Peferoen M (1991) Proc. Natl. Acad. Sci. USA. 88: 5119-5123

Forcada C, Alcacer E, Garcera MD, and Martinez R (1996) Arch. Insect Biochem. Physiol. 31: 257-272
Gould F, Anderson A, Landis D, and Van Mellaert H (1991) Entomol. Exp. Appl. 58: 199-210

Gould F, Anderson A, Jones A, Sumerford D, Heckel DG, Lopez J, Micinski S, Leonard R, and Laster M (1997) Proc. Natl. Acad. Sci. USA. 94: 3519-3523

Heckel DG (1994) Biocontrol Sci. Technol. 4: 405-417

Jongsma MA, Stiekema WJ, and Bosch D (1996) Trends Biotechnol. 14: 331-333

Keller M, Sneh B, Strizhov N, Prudovski E, Regev A, Koncz C, Schell J, and Zilberstein A (1996) Insect Biochem. Mol. Biol. 26: 365-373

Krattiger AF (1997) Insect Resistant Crops: A Case Study of Bacillus thuringiensis (Bt) and its Transfer to Developing Countries. International Service for the Aquisition of Agri-Biotech Applications. ISAAA Briefs No 2. ISAAA, Ithaca, NY

Liu Y-B, and Tabashnik BE (1997) Appl. Environ. Microbiol. 63: 2218-2223

Mallet J, and Porter P (1992) Proc. R. Soc. Lond. B 250: 165-169

Mazier M, Pannetier C, Tourneur J, Jouanin L, and Giband M (1997) Biotech. Annual Rev. 3: 313-347

McGaughey WH and Whalon ME (1992) Science 258: 1451-1455

Oppert B, Kramer KJ, Beeman RW, Johnson D, and McGaughey WH (1997) J. Biol. Chem. 272: 23473-23476

Rajamohan F, Alzate O, Cotrill JA, Curtiss A and Dean D (1996) Proc. Natl. Acad. Sci. USA. 93: 14338-14343

Ramachandra S, Buntin GD, All JN, Raymer $P L$, and Stewart CN (1998) Environ. Entomol. 27: 649-656

Stone TB and Sims SR (1993) J. Econ. Entomol. 86: 989-994

Tabashnik BE (1994a) Ann. Rev. Entomol. 39:47-79

Tabashnik BE (1994b) Proc. R. Soc. Lond. B 255: 7-12

Tabashnik BE, Finson N, Johnson MW, and Moar WJ (1993) Appl. Environ. Microbiol. 59: 1332-1335

Tabashnik BE, Liu Y-B, Finson N, Masson L, and Heckel DG (1997) Proc. Natl. Acad. Sci. USA. 94: 1640-1644 